\title{
PRIORITIZING INNOVATION FACTORS BY USING ANALYTIC NETWORK PROCESS
}

\author{
Fulya TAŞEL ${ }^{1}$, Ebru Beyza BAYARÇELİK ${ }^{2}$, Sinan APAK $^{3}$
}

\begin{abstract}
The emergence and development of the fourth industrial revolution affects production systems. This new revolution also has an impact on logistics, which has a direct relationship with production. Organizations give importance on innovation, technological change and product differentiation to compete with their rivals. Innovativeness creates better understanding of customer needs and wants, catch up their rivals and become more proactive in seeking the market opportunities for organizations. Therefore, improving logistics services using innovations can help improving strong customer relationships, derive barriers to competition, increase customer loyalty, change costs and conduct market activities more effectively. In this context, the objective of this study is to prioritize the innovation factors in logistics industry using a pairwise comprehensive method named Analytic Network Process (ANP). This model is proposed to define a ranking between selected criteria for innovation based decisions. This methodology demonstrates, which criteria has the most important role in the innovation processes.
\end{abstract}

Keywords: ANP, Decision-making, Innovation, Logistics Industry.

JEL Classification: L80, O30, J44

\section{YENILIIK FAKTÖRLERININ ANALITTIK AĞ SÜRECİ KULLANARAK ÖNCELIKLENDİRILMESI}

Öz

Dördüncü sanayi devriminin ortaya çıkışı ve gelişmesi üretim sistemlerini etkilemektedir. $\mathrm{Bu}$ yeni devrimin, üretim ile doğrudan ilişkisi olan lojistik üzerinde de etkisi bulunmaktadır. Örgütler, rakipleriyle rekabet edebilmek için inovasyon, teknolojik değișim ve ürün farklılaşmasına önem vermektedirler. Yenilikçi olmak, müşteri ihtiyaç ve isteklerini daha iyi anlamak, rakiplerini yakalamak ve pazar firsatlarını aramada işletmeleri daha proaktif hale getirir. Bu nedenle, yenilikleri kullanarak lojistik hizmetlerini iyileştirmek, güçlü müşteri ilișkilerini geliștirmeye, rekabete engel olușturmaya, müșteri sadakatini arttırmaya, maliyetleri değiştirmeye ve piyasa faaliyetlerini daha etkin bir şekilde yürütmeye yardımcı olmaktadır. $\mathrm{Bu}$ bağlamda, bu çalışmanın amacı, lojistik sektöründeki inovasyon faktörlerini Analitik Ağ Süreci (AAS) olarak adlandırılan bir yöntem kullanarak önceliklendirmektir. Bu model, inovasyona dayalı kararlar için seçilen kriterler arasında bir sıralama oluşturmak için önerilmiştir. Bu metodoloji, inovasyon süreçlerinde hangi kriterlerin en önemli role sahip olduğunu göstermektedir.

Anahtar kelimeler: AAS, Karar Verme, İnovasyon, Lojistik Endüstrisi.

JEL Sinıflaması: L80, O30, J44

1 Asst. Prof. Fulya Taşel, Maltepe University, Faculty of Business and Management Sciences, Department of International Trade and Logistics Management, Istanbul, fulyatasel@ maltepe.edu.tr, ORCID ID: 00000001-6959-5776

2 Asst. Prof. Ebru Beyza Bayarçelik, Maltepe University, Faculty of Business and Management Sciences, Department of International Trade and Logistics Management, Istanbul ebrubeyzabayarcelik@maltepe.edu.tr, ORCID ID: 0000-0003-4886-5719

3 Assoc. Prof. Sinan Apak, Maltepe University, Faculty of Engineering and Natural Sciences, Department of Industrial Engineering, Istanbul, sinanapak@ maltepe.edu.tr, ORCID ID:0000-0002-3263-7167 


\section{Introduction}

With the globalization of the economy and increase of competitive pressure, many companies have tried to shape their costs and service advantages by continuously improving their logistics performances. Logistics industry is critical example of the birth and development of a vital new service-based industry, that transformed from the business concept of transportation to that of serving the entire logistical needs of customers (Chapman et al., 2003). For a global world, an effective logistics operation can provide a competitive advantage for companies and increase a company's market share (Daugherty et al., 1998; Mentzer et al., 2001). Globalization stimulate organizations to find new markets, increase their production rates and resource efficiency which logistics plays a crucial role in the transportation of materials, products and services through the supply chain. Therefore, logistic operations are capable of reducing costs and providing delivery solutions according to the customer's need, that focuses on enhancing customer satisfaction by adding value, which also adds value to overall firm's output (Grawe, 2011). Logistic operation success depends on adaptability to the challenges of their industry environment in rapidly changing competitive environment (Daugherty et al. 2011). Although the opportunity to create a competitive advantage through logistics, has inspired researchers and practitioners to consider diverse critical factors leading to higher levels of logistics performance, there is not clear and exact definition of innovation concept in logistic service. In fact, in 2005 Flint and his friends stressed out that logistics research has largely ignored innovation. After understanding the importance of innovation in logistics, researchers have started to study on new innovative improvements in the logistics firms. These researchers have suggested some innovative activities such as focusing on customer value orientation (Flint et al., 2005, Busse 2010; Busse and Wallenburg 2011), technologies for logistics service providers (LSP) (Lin, 2007; Hsu and Wallace, 2007), the new business strategy (Chapman et al. 2003; Kim et al., 2012), external relations with LSP (Bellingkrodt and Wallenburg, 2013; Dai, 2015) and adoption of logistic innovation (Tanskanen, 2015) to help logistics firms to identify which key factors can create competitive advantages through successful innovative activities.

The purpose of this research is to examine which external and internal factors affect innovation decisions in logistics firms. To answer this question, firstly the criteria are defined according to logistic innovation literature and then Analytic Network Process (ANP) model is used to find out which criteria are most important for logistics industry. In the second section of this paper the relation between innovation and logistics is examined and the descriptions of criteria are explained. After that, in the third section the decision making methodology is given and the results are discussed. Finally, fourth section tries to give some concluding remarks.

\section{Innovation and Logistics}

In a modern business environment, characterized by demanding customers, higher competition, and uncertainty, innovation is a major contributor to the long-term success and growth of a firm (Cichosz et al., 2017). 
Today, logistics goes beyond the role of traditional role in "transportation" to offer its customers' a strategic weapon to create sustainable competitive advantage.

Improving logistics services using innovation can help develop strong relationships with customers, derive barriers to competition, increase customer loyalty, change costs and conduct market activities more effectively. For logistics firms that serve the market in the new economy, technology, knowledge and relationship networks are three necessity for service innovation (Chapman et al., 2003). The current progress of the logistics industry is focused on innovative management approach which means companies that will increase the use of the new management process to systematically implement and improve (Viederyte, 2016). Logistics innovation has been defined as any logistics-related service that is regarded as new and helpful to a particular focal audience (Flint et al. 2005).

Innovation in the service sector is described by Sundbo and Gallouj (1999) as an incremental innovation in which small adjustments are made to processes and are rarely expressed as radicals (Sundbo \& Gallouj, 1999). On the other hand, service innovation is seen as a multidimensional process and its organizational aspect is dominant when compared with the production sector. Service organizations use innovation to improve market performance and efficiency, such as cost-effectiveness, productivity, quality of service, inventory management, process improvement, value, price and information. These developments have become the main drivers of market competition in the services industry (Chapman et al., 2003).

Angeleanu (2015) stated that "the explosion in global trade that has occurred in the last two decades is in part a reflection of the innovations in logistics [...] that have led to a reduction in the costs of shipping goods and services across borders". Logistics innovation can range from very basic to very complex, and can be applied to internal operations or services with business partners (Cichosz et al., 2017).

There are two important classification of innovation, incremental and radical innovations. Incremental innovations indicate minor changes and usually takes place in the process of efficiency improvement. Radical innovations, at the same time known as revolutionary innovations or destructive innovations and are recognized by the customers and have a direct effect on them. Some examples of radical innovation as a process innovation are, introduction of the standardized container on a mass scale in international trade, developing cross-docking, introduction of Vendor Managed Inventory (VMI). Technological innovations for logistics include Materials Resource Planning (MRP) systems, Electronic Data Interchange (EDI), Global Positioning Systems (GPS), barcoding, RFID tags and so on. In addition to incremental innovations, radical ones not only reduce cost and time, but also increase the consistency and flexibility of logistics operations (Cichosz et al., 2017). 
Viederyte (2016) argues that the development of process innovations in transport, logistics and e-systems will be determined by growing passenger and goods carriage flows and the cargo handling volumes; increasing concentration of people in cities, resulting in uneven loading of road infrastructure and increasing traffic jams; increasing pollution of the environment and the greenhouse effect; stronger competition because of third countries which lowers prices. Therefore, to stay competitive innovation is important for logistics and transportation.

Service quality and consumer expectations are constantly increasing for safer, environmentally friendly and faster transportation. Angeleanu (2015) supported that new technological trends in logistics (Cloud Logistics, Supergrid Logistics, Anticipatory Logistics, Omni-Channel Logistics and Additive Manufacturing like 3D Printing) have a positive impact on logistics and supply chain processes, improve the performance of companies, increase efficiency and provide lower logistics costs.

\subsection{Descriptions of Criteria}

Based on the literate review and the results of discussions with stakeholders, four priority criteria and sub-criteria were identified by the group of experts. Table 1 shows the four main criteria; firm structure, economic environment, technological innovation criteria and internal environment criteria and sub-criteria selected to find out which factor is the most influencing factor of innovation decision for logistic firms.

Table1. Main and sub criteria relationship diagram

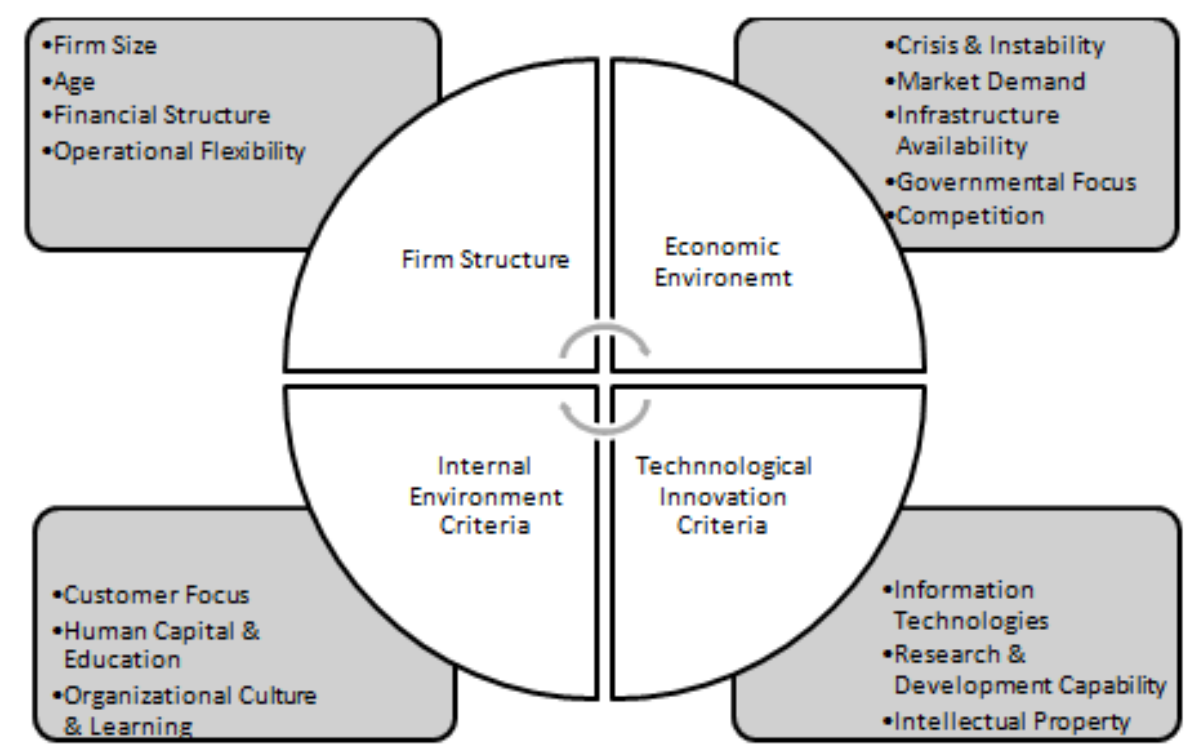

\subsection{Technological Innovation Criteria}

Technological innovation factors are studied by many researchers like Baark et al., (2011), Christensen (1995), Burgelman et al., (2004), Yam. et al., (2004) to draw underestimations, approaches and components to find out a firm's technological or innovation capabilities. 
Technological capability refers that technological readiness, consists of research and development activity, information technology (IT) infrastructure, R\&D professions and ability to create intellectual property (Sumrit and Anuntavoranich, 2013).

a. Information Technologies: Information technologies (IT) are essential source of competitive advantage and improved productivity for logistics industry.

So IT's are infrastructures to make communications for managing business-to-business relations more efficiently, and the aggregation of IT systems of cooperating partners increases organizational flexibility and readiness to respond to changing environment at minimized costs (Rajaguru and Matanda, 2013). There are different informational portal such as Electronic data interchange (EDI), the Internet, value added network (VAN), point of sales (POS), electronic ordering system (EOS), logistics information system, computer telephony integration and enterprise that are commonly used portals in logistics industry (Lin, 2008). On the other hand customer services are very important for logistic services to create customer satisfaction and loyalty. According to Jiebing and Yongjiang (2013); “Customer knowledge management with IT application is positive related to value delivery in business model innovation through increasing knowledge accessibility for both firms and customers". ERP (Enterprise Resource Planning) and CRM (Customer Relationship Management) are new systems that combine technology and process to enable logistic services, in which allows higher standards for customer service. ERP is a system that enables enterprises to use the labor force, machines and materials, they need to produce products and services efficiently, on the other hand CRM systems are used to create and continue ties with customers to gain earnings (Rajaguru and Matanda, 2013). In logistic services, companies use information technologies to decrease cost of production by optimization and to increase customer relations (Mesjasz-Lech, 2015).

b. Research \& Development Capability: Research and Development (R\&D) operations are the most crucial part of the technological innovation and intangible investments are critical to organizations (Evangelista et al.,1997). According to OECD, Research and development is “... comprise creative work undertaken on a systematic basis in order to increase the stock of knowledge, including knowledge of man, culture and society, and the use of this stock of knowledge to devise new applications" (OECD,2005). Many studies are tried to define antecedent factors of firm innovation capabilities (Christensen, 1995; Chiesa et al., 1996; Burgelman et al., 2004, Yam et al., 2004). The R\&D capability which is emphasizing creativity, creating new value for customers, and increasing innovation to tap the various facets of innovation capability (Calantone et al., 2002), is the intersection point of these studies. The basic functions of R\&D capabilities of firm are to expand its existing technologies and establish new technologies or improve R\&D functions. 
The number of researchers (employees of $R \& D$ department), success rate of $R \& D$ product or services, self-generated innovative products and R\&D intensity are the basic content of the R\&D capabilities (Wang et al., 2008).

c. Intellectual Property: In the service economy, intellectual property (IP) is a key component in "creating an image for your business in the minds of your current and potential customers and in positioning your business in the market" (Sukarmijan and Sapong, 2014). Strong IP rights led to increased use of intangible assets, such as trademarks, brands and patents in licensing and commercialization activities (Arora and Fosfuri, 2003). Companies must protect their intellectual property in order to generate revenue from their innovative capacity and creativity for further innovation investment.

On the other hand, intellectual rights are used with marketing mix such as advertisement, PR applications, sales \& promotion activities, that differentiate organization product and services, that consumers can easily identify and differing marketing strategies (Sukarmijan and Sapong, 2014).

\subsection{Economic Environment Criteria}

There is an important relationship between the economic environment and the innovation performance of firms.

a. Crisis\&Instability: The economic crisis makes business opportunities less precise, making companies less willing to invest in long-term activities where returns are risky. Most companies react by reducing spending, including investment and innovation (Archibugi et al., 2013). The research of Paunov (2012) provides a quantitative analysis on Latin American firms' innovation performance during the 2008-2009 global crisis period. The research findings indicate that investments in innovation decreased significantly for during the 2008-2009 global crisis and one in four firms cut back on innovation projects. In addition, participating in such projects is important for the development of technological performance, and the global crisis may adversely affect firms' decisions on innovation (Paunov, 2012). Besides, economic crises allow businesses, industries and all nations to reorganise productive facilities and search for new opportunities. Smart companies think that the economic crisis will not last forever and that the recovery will come sooner or later (Archibugi et al., 2013).

b. Market Demand: Demand factors; customers, tastes, customs and purchasing power are important factors that can affect a country's innovativeness (Fabrizio et al, 2017). In today's world the demands are increasing and companies must be ready to respond these changes. If management can sense these changes they can be organized and ready to meet the new requirements (Grawe et al., 2011).

c. Infrastructure Availability: Infrastructure is one of the important factors which generate opportunities and arises from physical assets, human capital, and general technical structure. 
Conceicao et al. indicates that, for knowledge based economies infrastructure for education, called as knowledge infrastructure, is also important. The education system, research and teaching activities are important indicators of infrastructure for education.

Another important factor for innovation in knowledge-based economies is technological infrastructure, which consists of science, engineering, and technical knowledge available to industry (Conceicao, Heitor, \& Francisco, 2003). Basic research infrastructure and institutional infrastructure are important factors for a country’s innovativeness (Fabrizio et al, 2017).

d. Governmental Focus: A country's innovativeness is seen as the outcome of several factors, a government policy is one of those important factors that may promote innovation (Fabrizio et al, 2017). The governmental factors such as regulations, the legal environment, the efficiency or the effectiveness of the government (public utilities, public transportation, security, education and health...) has an important effect on innovation.

Also the government policies can affect the potential of firm innovation and also can contribute or prevent the firm's innovation and economic welfare (Guan \& Yam, 2015). Patanakul and Pinto (2014) suggested that government should have innovation policies that act in combination in both direct and supporting roles for promoting and sustaining innovations. The government should maintain a set of innovation policies that defines clear targets that can boost firms toward technological changes. Kim et. al. (2012) supported that patent protection is a critical determinant of innovation and that patentable innovations contribute to economic growth.

e. Competition: For innovation strategies the sectoral environment affects the strategic decision making of the managers. While competitive environments are difficult for firms, they may require firms to be more innovative in order to compete with rivals. Wang and Dass (2017) supported that in a more competitive environment, managers should be careful in their strategic decision, the higher risk associated with greater competition may reduce firms' innovation activity. Global competition has changed the rules for managing the innovation function of multinational corporations (MNCs). The companies that are competing globally need to promote innovative products, services and processes globally, quickly and effectively. Sustainable competitive advantage is largely based on the ability to access and process worldwide market and technology knowledge to accelerate and improve the innovation output (Fallah \& Lechler, 2008). Fabrizo et al. (2017) supported that there are several factors affecting the innovativeness of the country. Competitiveness of the market in which the firms are competing is one of those important factors. 


\subsection{Firms Structure Criteria}

a. Firm Size: Firm size is a critical factor affecting the decision of long-term or short-term strategies. For instance small and medium enterprises (SMEs) is short-term oriented rather than large enterprises for strategic planning (Hwang, Hwang, \& Dong, 2015). Hwang et al. point out several important differences related with the firm size. For example, large enterprises can suggest higher wages and security with their huge financial assets to attract skilled and experienced labor, particularly scientists and engineers. This is not easy for SMEs to provide this. Moreover, large enterprises often have the required financial assets that let them resist to the failure or bad results of R\&D projects (Hwang, Hwang, \& Dong, 2015).

Pellegrino and Savona stated that larger firms are probably deal with innovation activity because they are less probable to be influenced by liquidity restraints and can benefit from economies of scale. (Pellegrino \& Savona, 2017). Cobo-Benita et al. (2016) stated that a combination of large firm size, cooperation with international partners and organizational innovation, is a sufficient condition for success in innovation performance.

b. Age : In literature there are several studies which have focused on how innovation behavior changes with the age of the firm. There are two opposite views regarding the affect of firm age on innovation. Indeed, researches suggested that there may be both negative and positive influences of firm age (Coad, Segarra, \& Teruel, 2016; Sorensen and Stuart 2000).

The fact that older firms have learning effects allows them to innovate more effectively with their past experience and skills. In addition, older companies can accumulate resources, managerial knowledge, as well as the ability to accumulate reputation and market (Coad, Segarra, \& Teruel, 2016). Also, as organizations age, they produce more innovations, or their ability to produce new innovations or patents seems to develop with age (Sorensen and Stuart 2000). Besides older firms may face with number of challenges related with the firm's ability to change. With respect to small firms, there may also be counter effects. For example, younger firms do not start with their routines and abilities and need to build them quickly for entry (Coad, Segarra, \& Teruel, 2016). Sorensen and Stuart supported that the increasing distance between the organization's innovative capabilities and the technological frontier creates possibilities for new firms whose internal routines are more compatible with the current state of technological development. In addition, it is seen that many important innovations are pioneered by young, entrepreneurial companies (Sorensen and Stuart 2000). The challenge is for young firms, starting from the beginning, they should quickly set and also catch up higher-level of innovation capabilities. Young firms may therefore initially lack the internal capabilities to benefit from $R \& D$ investment. Coad et al. indicates that young firms have specific innovation drawbacks, and that they participate in riskier $R \& D$, although over time the returns to $\mathrm{R} \& \mathrm{D}$ become more predictable. In addition, innovation by younger firms is more likely to be associated with employment growth (Coad, Segarra, \& Teruel, 2016). 
c. Financial Structure: To promote the development of innovation, firms should increase their R\&D expenditure. Innovation spending may involve several different types of costs such as wages and salaries of research personnel, skilled workers, educated scientists, engineers and other specialists. Because of processes characterizing R\&D (investigation, preparation, incubation, illumination, verification and application), innovation activities are generally considered as long-term projects.

Firms are ambiguous about how much effort and material is needed to finish each project, or how market demand will be (Guariglia and Liu, 2014). Evaluating long-term and risky projects and diversifying risk will crucially affect the financing of innovation (Hsu et al., 2014).

Some studies in literature about innovation and finance point out high innovation potential for firms (Pellegrino \& Savona, 2017). Because of the asymmetric information between shareholders, creditors and firm managers, together with limited liability, financial structure effects the firm's investment, innovation or output (Maurer, 1999). Asymmetric information also generates moral hazard problems, resulting in conflicts of interest between shareholders and managers (Guariglia and Liu, 2014).

d. Operational Flexibility: In order to improve innovation, companies invest extremely in the development of technological capabilities that offer the skills and abilities to use variety of resources and know-how. Zhou and $\mathrm{Wu}$ stated that, as organizational capabilities increase in a specific field, it encourages further utilization in that area.

As companies increase their experiences and become more efficient in using their available knowledge, the self-reinforcing nature of learning leads to more productive activities. Strategic flexibility reinforces the positive impact of technological capability on research; that is, when strategic flexibility is high, more technological capability is associated with more explorative innovation (Zhou and $\mathrm{Wu}, 2010$ ). Technological innovation offers the promise of more adaptable and streamlined production processes. Flexible technologies enable a firm to continuously enhance operational decisions in response to fluctuations in the market (Mittendorf, 206). Because of the globalization, the development of information technology, and the variety of customer requirements make many businesses face highly volatile and uncertain environments resulting from short product life cycles and frequent and uncertain changes in demand. For such enterprises, flexibility has increasingly become a core strategic competency (Yu et al., 2015). Especially in times when the economic conditions are violent, buyers tend to be more conservative and more cautious in placing orders. And also in times of uncertainty buyers are not so willing to hold inventory. This generates an expectation of quick response when they place an order. In these situations also operational flexibility gains importance to meet the market demands (Grawe et al., 2011).

\subsection{Internal Environment Criteria}

Organizational factors are important as contextual factors on influencing organizational innovation. 
In research's, scholars are become more concerned on capabilities like organizational innovation that are already embedded in firms. They emphasize the importance of customerfocused, human capital \& education, organizational culture \& learning, leadership and management skills for innovation in firm's performance (Pedrosa, 2015; Flint et al, 2008).

a. Customer Focus: In today's business environment, customer focus is distinctive competence for all kind of companies.

According to recent studies, if company wants to make innovation in its logistics operations, they have to identify and understand their customers' needs (Pedrosa et al, 2015; Flint et al, 2008). For this reason, the researchers involve customers in innovation development processes to increase both firm performance and customer acceptance and utilization rates in organizations (Flint et al., 2008; Wagner and Sutter, 2012). According to Flint (2008) understanding the dynamics of customer value perceptions offers significant opportunities for logistics innovation. In parallel with, managers can understand logistics relevant changes in customer perceptions regarding functional, service, and relationship desires, and monetary and non-monetary sacrifices.

b. Human Capital \& Education: One of the most important resource for innovation is individual knowledge stock of its employees. Human capital defines as knowledge resources that consist of skills, experience, expertise, ideas, knowledge, competencies, abilities and values of employees inside organization (Bontis , 2001; Youndt et al, 2004).

In addition, Hudson (1993) added combination of genetic heritance, education, experience, attitude about life and business can also shape the human capital of organizations. Human capital is both supportive and essential for innovation performance because employee's knowledge, expertise and competencies are vital in today's complex and dynamic competitive environments (Hsu and Wang, 2012; Subramanian and Youndt, 2005). Organizations which has wide variety of human capital can be more entrepreneur that can proactive to market opportunities, easily and speedly to take risks and refuse threats (Han and Lin, 2014). By the way human capital can minimize decision making mistakes and so increase innovation performance (Luthans and Youssef, 2004). Martín-de-Castro and friends (2011) claimed that "High-quality talents with good education and sophisticated skills can develop increased cognitive abilities, leading to more productive and efficient activity to improve their job performance, which helps enterprises have better entrepreneurial judgment, run business more smoothly and ultimately improve the firm's innovative performance" (Martín-de-Castro et al., 2011).

c. Organizational Culture \& Learning: In organizations, innovation performance success is closely related with implementing creative ideas within the organization by organizational learning (OL). According to Arago'n and his colleagues organizational learning is "a collective capability based on experiential and cognitive processes and involving knowledge acquisition, knowledge sharing, and knowledge utilization" (Arago'n-Correa et al.,2007). 
Concurrently OL creates firm climate that values experimentation and risk taking, applies new knowledge \& ideas, tolerates mistakes and failures, rewards nontraditional thinking and increases ability to understand and apply them (Arago'n-Correa et al., 2007). Learning process in organization covers searching for information, assimilating, developing and creating new knowledge on products, processes, and services (Bayarçelik, Taşel \& Apak, 2014).

Previous studies proposed that organizational learning influences on organizational performance (Wheelwright and Clark, 1992; Hult et al., 2004; Alegre and Chiva, 2008; Flint et al., 2005, 2008). McKee (2005), suggested that product innovation as an organizational learning and he added that routing the organization towards learning supports innovation effectiveness and efficiency. Hult and his friends (2004) proposed that if a firm has been qualified as an innovative, management must build and encourage the organizational climate and systems that embody a clear learning orientation. On the other hand, Panayides and So (2005) study's which is investigating logistic innovation, showed that organizational learning mediates the relationship between relationship orientation and logistics innovation.

Also Flint's (2008) found out the relationship between knowledge and logistics innovation as they pointed out a direct positive relationship between supply chain learning and logistics innovation.

d. Management Skills and Leadership: The effects of the manager and the leader on innovation processes are discussed from different perspectives in literature.

Middle and top managers are required organizational capability to create innovative culture for employees in organizations and they are facilitators of innovation in existing companies (Covin and Miles, 1999). In addition executives encourage entrepreneurial thinking by allowing autonomy to produce creative proposals, obtaining support funding from internal stakeholders, form a concurrence decision-making between senior management team (Börjesson et al. 2014). Besides, they can create an innovative organizational climate by promoting self- development, new learning techniques, supporting to take risk (Un, 2010; Yang, 2012). Management team are also accountable for developing working environment that encourage the new innovative ideas, research and development on new technologies such as cloud computing, artificial intelligence, augmented reality, and support their adoption of innovative thinking (Jassawalla and Sarshittal, 2002).

\section{Research Method}

\subsection{The Decision Making Methodology}

The Analytic Network Process Model (ANP) is a method used to measure intangible factors by using pairwise comparisons with judgments that represent the dominance of one element over another with respect to a property that they share. Various criteria make decision problem complex and time consuming. 
In this study to analyze priorities analytic network process is applied. Basic ANP structure is given step by step to define firstly comparison matrix then weighting each criterion.

Step 1: Decision goals

Decision maker/s has/have to determine decision goal/s at the beginning of phase. According to goal decision maker determines the decision model to select appropriate methodology.

Step 2: Gathering decision criteria

Starting from goals, define criteria starting from in the lower and middle level hierarchical structure with alternatives.

Step 3: Solving model

The purpose of ANP is establishing binary comparisons between criteria and alternatives that references the 1-9 scale created by Thomas L. Saaty (1996) as shown in Table 2. These priorities are derived, based on pairwise assessments using judgment, or ratios of measurements from a scale if one exists. The process of prioritization solves the problem of having to deal with different types of scales, by interpreting their significance to the values of the decision maker/s.

Table 2. Scale of relative importance

\begin{tabular}{|l|l|}
\hline Intensity of Importance & Definition \\
\hline 1 & Equal importance \\
\hline 2 & Weak \\
\hline 3 & Moderate importance \\
\hline 4 & Moderate plus \\
\hline 5 & Strong importance \\
\hline 6 & Strong plus \\
\hline 7 & Very strong \\
\hline 8 & Very, very strong \\
\hline 9 & Extreme importance \\
\hline
\end{tabular}

Source: Saaty $(1997,1980)$

A ratio scale is a set of numbers that is invariant under a homogeneous attribute transformation (multiplication by a positive constant). The constant rescinds when the ratio of any two numbers is composed. The local weight vectors obtained in the second step are placed in the supermatrix in positions corresponding to the representative elements in the row in the affecting column.

On the first level we consider a decision goal $\mathrm{G}$, on the second level, we have $\mathrm{n}$ independent evaluation criteria: $\mathrm{C} 1, \mathrm{C} 2, \ldots, \mathrm{Cn}$, such that $\sum_{i=1}^{n} w\left(C_{i}\right)=1$, where $\mathrm{w}(\mathrm{Ci})>0, \mathrm{i}=1,2, \ldots, \mathrm{n}, \mathrm{w}(\mathrm{Ci})$ is a positive real number - weight, or, relative importance of criterion Ci subject to the goal G. 
On the third level $\mathrm{m}$ variants (alternatives) of the decision outcomes $\mathrm{V} 1, \mathrm{~V} 2, \ldots, \mathrm{Vm}$ are considered such that again $\sum_{r=1}^{m} w\left(V_{r}, C_{i}\right)=1$, where $w(\mathrm{Vr}, \mathrm{Ci})$ is a non-negative real number - an evaluation (weight) of $\mathrm{Vr}$ subject to the criterion $\mathrm{Ci}, \mathrm{i}=1,2, \ldots, \mathrm{n}$. This system is characterized by the supermatrix $\mathrm{W}$ :

$$
\mathrm{W}=\left[\begin{array}{ccc}
\mathbf{0} & \mathbf{0} & \mathbf{0} \\
\mathbf{W}_{21} & \mathbf{0} & \mathbf{0} \\
\mathbf{0} & \mathbf{W}_{32} & \mathbf{I}
\end{array}\right]
$$

where $\mathrm{W} 21$ is the $\mathrm{n} \times 1$ matrix (weighing vector of the criteria), i.e.

$$
\mathbf{W}_{21}=\left[\begin{array}{c}
w\left(C_{1}\right) \\
\mathrm{M} \\
w\left(C_{n}\right)
\end{array}\right]
$$

and $\mathrm{W} 32$ is the $\mathrm{m} \times \mathrm{n}$ matrix:

$$
\mathbf{W}_{32}=\left[\begin{array}{ccc}
w\left(C_{1}, V_{1}\right) & \Lambda & w\left(C_{n}, V_{1}\right) \\
\mathrm{M} & \Lambda & \mathrm{M} \\
w\left(C_{1}, V_{m}\right) & \Lambda & w\left(C_{n}, V_{m}\right)
\end{array}\right]
$$

The columns of this matrix are evaluations of variants by the criteria, I is the unit matrix. $\mathrm{W}$ is a column-stochastic matrix, i.e. the sums of columns are equal to one. Then the limit matrix $\mathrm{W} \infty$ (we can calculate the resulting priority vector of weights of the variants $\mathrm{Z}$ which is given by formula (4). The variants can be ordered according to these priorities.

$$
\mathrm{Z}=\mathrm{W} 32 \mathrm{~W} 21
$$

In real decision systems with 3 levels there exist typical interdependences among individual elements of the decision hierarchy e.g. criteria or variants. Consider now the dependences among the criteria. This system is then given by the supermatrix $\mathrm{W}$ :

$$
\mathrm{W}=\left[\begin{array}{ccc}
\mathbf{0} & \mathbf{0} & \mathbf{0} \\
\mathbf{W}_{21} & \mathbf{W}_{22} & \mathbf{0} \\
\mathbf{0} & \mathbf{W}_{32} & \mathbf{I}
\end{array}\right]
$$

where the interdependences of the criteria are characterized by $n \times n$ matrix $W 22$ :

$$
\mathbf{W}_{22}=\left[\begin{array}{ccc}
w\left(C_{1}, C_{1}\right) & \Lambda & w\left(C_{n}, C_{1}\right) \\
\mathrm{M} & \Lambda & \mathrm{M} \\
w\left(C_{1}, C_{n}\right) & \Lambda & w\left(C_{n}, C_{n}\right)
\end{array}\right] .
$$


In general, matrix (5) is not column-stochastic, hence the limiting matrix does not exist. Stochasticity of this matrix can be saved by additional normalization. Then there exists a limiting matrix $\mathrm{W} \infty$ and the vector of weights $\mathrm{Z}$ can be calculated by formula (6).

$$
\mathbf{Z}=\mathbf{W}_{32}\left(\mathbf{I}-\mathbf{W}_{22}\right)^{-1} \mathbf{W}_{21}
$$

As the matrix W22 is close to the zero matrix, as the dependences among the criteria are usually weak, it can be approximately substituted by the first 4 terms and we get:

$$
\mathbf{Z}=\mathbf{W}_{32}\left(\mathbf{I}+\mathbf{W}_{22}+\mathbf{W}_{22}^{2}+\mathbf{W}_{22}^{3}\right) \mathbf{W}_{21}
$$

For group decision making, judgments must be combined so that reciprocal of the synthesized judgments must be equal to equal synthesis so that geometric mean is a unique way to do that (Saaty,1990).

\subsection{Prioritizing Innovation Factors}

Our importance identification model includes firm structure, technological factors, internal environment, and economic environment.

Firm structure (A) includes such sub-criteria that firm size (A1), age (A2), financial structure (A3), operational flexibility (A4); technological factors (B) includes research and development (B1), information technology (B2), intellectual property rights (B3); internal environment (C) includes customer focus (C1), human resources and education (C2), organizational culture (C3), organizational learning (C4), leadership (C5), and management skills (C6); economic environment (D) includes crisis and instability, market demand, infrastructure availability, government focus, and competition. When those criteria compared with each other relation matrix is found in Table 3 and 4. Those " $x$ " represent there is a meaningful relationship for decision makers. That means at least one of the decision makers found that relationship.

Survey based on pairwise comparison of each criterion conducted to logistics industry. Survey sent to 82 logistics firms in Turkey and 39 relevant survey accepted. When 39 decision makers considered it is fair enough to give an idea about survey results. ANP consider each decision member as a group member. So 39 group member making tends to give better results because of the broader knowledge available and also because of the possibility of debates that may arise and change people's understanding — such changes in understanding that lead to improvements in the model or judgments are an important aspect of this process that can lead to improved decisions (Whitaker, 2007 ). Data were collected considering analytic network structures from pairwise questionnaires from 39 experts in the logistics field, with at least three years' experience in the strategic innovation of logistics operations. The number of decision makers in terms of model work is sufficient because methodology is sufficient for at least one decision maker for the decision-making problems to make a decision (Saaty, 1990). 
39 members reflect the general view of a segment applied here. That is, group decision making is used. The data received were statistically processed accordingly in a preliminary study of the authors.

The cluster themselves must be compared to establish their relative consequentiality and utilize it to weight the corresponding blocks of the supermatrix to make it column stochastic.

A cluster impacts another cluster when it is linked from it, that is, when at least one node in the source cluster is linked to nodes in the target cluster. The process is reiterated for each cluster in the network to obtain the matrix. The clusters are withal pairwise compared to establish their consequentiality with veneration to each cluster they are linked from, and the resulting matrix of numbers is utilized to weight the corresponding blocks of the pristine unweighted supermatrix to obtain the weighted supermatrix. This matrix is then raised to powers until it converges to yield the constraint supermatrix. The relative values for the companies are obtained from the columns of the inhibition supermatrix that in this case are all the same because the matrix is irreducible.

Table 3. ANP relationship matrix

\begin{tabular}{|c|c|c|c|c|c|c|c|c|c|c|}
\hline & & \begin{tabular}{|l|} 
Firm \\
Structure
\end{tabular} & & & & \begin{tabular}{|l|} 
Technological \\
Factors
\end{tabular} & & & \begin{tabular}{|l|} 
Internal \\
Environment
\end{tabular} & \\
\hline & & Firm Size & Age & \begin{tabular}{|l} 
Financial \\
Structure
\end{tabular} & $\begin{array}{l}\text { Operational } \\
\text { Flexibility }\end{array}$ & \begin{tabular}{|l} 
Reseach \& \\
Development
\end{tabular} & $\begin{array}{l}\text { Information } \\
\text { Technology } \\
\end{array}$ & \begin{tabular}{|l|} 
Intellectual \\
Propert \\
Rights \\
\end{tabular} & $\begin{array}{l}\text { Customer } \\
\text { Focus (MO) } \\
\end{array}$ & \begin{tabular}{|l} 
HR \& \\
Education
\end{tabular} \\
\hline \multirow[t]{4}{*}{ Firm Structure } & Firm Size & & & & & $\mathrm{x}$ & $\mathrm{x}$ & $x$ & & $\mathrm{x}$ \\
\hline & Age & & & & & $\mathrm{x}$ & & $\mathrm{x}$ & & \\
\hline & Financial Structure & & & & & $\mathrm{x}$ & $\mathrm{x}$ & $\mathrm{x}$ & & $x$ \\
\hline & Operational Flexibility & & & & & $x$ & $x$ & & $x$ & $x$ \\
\hline \multirow[t]{3}{*}{ Factors } & Reseach \& Development & & & & & & & & $\mathrm{x}$ & \\
\hline & Information Technology & & & & & & & & $x$ & \\
\hline & Intellectual Propert Rights & & & & & & & & & \\
\hline \multirow[t]{6}{*}{ Environment } & Customer Focus (MO) & & & & & & & & & \\
\hline & HR \& Education & & & & & & & & & \\
\hline & Organisational Culture & & & & & & & & & \\
\hline & Organisational Learning & & & & & & & & & \\
\hline & Leadership & & & & & & & & & \\
\hline & Management Skills & & & & & & & & & \\
\hline \multirow[t]{5}{*}{$\begin{array}{l}\text { Economic } \\
\text { Environment }\end{array}$} & Crisis \& Instability & & & & & & & & & \\
\hline & Market Demand & & & & & & & & & \\
\hline & Infrastructure Availability & & & & & & & & & \\
\hline & Governmental Focus & & & & & & & & & \\
\hline & Competition & & & & & & & & & \\
\hline
\end{tabular}


Table 4. ANP relationship matrix (cont.)

\begin{tabular}{|c|c|c|c|c|c|c|c|c|c|c|}
\hline & & & & & & \begin{tabular}{|l|} 
Economic \\
Environment
\end{tabular} & & & & \\
\hline & & $\begin{array}{l}\text { Organisational } \\
\text { Culture }\end{array}$ & \begin{tabular}{|l|} 
Organisational \\
Learning
\end{tabular} & Leadership & $\begin{array}{l}\text { Management } \\
\text { Skills }\end{array}$ & $\begin{array}{l}\text { Crisis \& } \\
\text { Instability }\end{array}$ & $\begin{array}{l}\text { Market } \\
\text { Demand }\end{array}$ & \begin{tabular}{|l} 
Infrastructure \\
Availability
\end{tabular} & \begin{tabular}{|l} 
Governmental \\
Focus \\
\end{tabular} & Competition \\
\hline \multirow[t]{4}{*}{ Firm Structure } & Firm Size & $x$ & $x$ & & $x$ & & $\mathrm{x}$ & & & $\mathrm{x}$ \\
\hline & Age & $\mathrm{x}$ & $\mathrm{x}$ & & & & & & & \\
\hline & Financial Structure & & & & & $x$ & $x$ & & $x$ & $x$ \\
\hline & Operational Flexibility & $x$ & $x$ & & & $x$ & $\mathrm{x}$ & & $x$ & $x$ \\
\hline \multirow[t]{3}{*}{\begin{tabular}{|l}
$\begin{array}{l}\text { Technological } \\
\text { Factors }\end{array}$ \\
\end{tabular}} & Reseach \& Development & $x$ & $x$ & & & & $x$ & & $x$ & $x$ \\
\hline & Information Technology & & & & & & $x$ & & $\mathrm{x}$ & $\mathrm{x}$ \\
\hline & Intellectual Propert Rights & & $\mathrm{x}$ & & & & $\mathrm{x}$ & & $x$ & $\mathrm{x}$ \\
\hline \multirow[t]{6}{*}{\begin{tabular}{|l|} 
Internal \\
Environment \\
\end{tabular}} & Customer Focus (MO) & & & & & & $\mathrm{x}$ & & & $\mathrm{x}$ \\
\hline & HR \& Education & & & & & & & & & \\
\hline & Organisational Culture & & & & & & & & & \\
\hline & Organisational Learning & & & & & $\mathrm{x}$ & $\mathrm{x}$ & & $x$ & $\mathrm{x}$ \\
\hline & Leadership & & & & & $x$ & & & & $x$ \\
\hline & Management Skills & & & & & $x$ & $x$ & & $\mathrm{x}$ & $\mathrm{x}$ \\
\hline \multirow[t]{5}{*}{\begin{tabular}{|l|} 
Economic \\
Environment \\
\end{tabular}} & Crisis \& Instability & & & & & & & & & \\
\hline & Market Demand & & & & & & & & & \\
\hline & Infrastructure Availability & & & & & & & & & \\
\hline & Governmental Focus & & & & & & & & & \\
\hline & Competition & & & & & & & & & \\
\hline
\end{tabular}

Criteria which are given in pairwise cooperation cluster for their influence on the criterion they are linked from to define the importance of their influence on the main criterion. Then, these priorities are then entered in the supermatrix for the network.

Table 5: Unweighted super matrix

\begin{tabular}{|c|c|c|c|c|c|c|c|c|c|c|c|c|c|c|c|c|c|c|}
\hline & $\overline{\mathrm{A}_{1}}$ & $\overline{\mathrm{A}_{2}}$ & $\overline{\mathrm{A}_{3}}$ & $\overline{\mathrm{A}_{4}}$ & $\mathrm{~B}_{1}$ & $3_{2}$ & $\overline{\mathrm{B}_{3}}$ & $\overline{\mathrm{C}_{1}}$ & $\mathrm{C}_{2}$ & $\overline{C_{3}}$ & $\mathrm{C}_{4}$ & $\overline{C_{5}}$ & $C$ & $\overline{P_{1}}$ & $\overline{\mathrm{D}_{2}}$ & $\mathrm{D}_{3}$ & D & $\mathrm{D}_{5}$ \\
\hline$\overline{A_{1}}$ & 0 & 0 & 0 & 0 & \multicolumn{4}{|c|}{0.0720 .2970 .0310} & \multicolumn{4}{|c|}{0.1990 .2570 .3190} & \multicolumn{2}{|c|}{0.0870} & \multicolumn{2}{|c|}{0.1680} & 0 & 0.126 \\
\hline $\mathrm{A}_{2}$ & 0 & 0 & 0 & 0 & \multicolumn{2}{|c|}{0.0390} & \multicolumn{2}{|c|}{0.0220} & 0 & \multicolumn{3}{|c|}{0.5030 .4420} & 0 & 0 & 0 & 0 & 0 & 0 \\
\hline$A_{3}$ & 0 & 0 & 0 & 0 & \multicolumn{4}{|c|}{0.0300 .1270 .0880} & \multicolumn{2}{|c|}{0.081} & 0 & 0 & 0 & \multicolumn{3}{|c|}{0.1330 .2150} & \multicolumn{2}{|c|}{0.1170 .206} \\
\hline $\mathrm{A}_{4}$ & 0 & 0 & 0 & 0 & \multicolumn{3}{|c|}{0.0940 .0360} & \multicolumn{5}{|c|}{0.0370 .1590 .2420 .4010} & 0 & \multicolumn{3}{|c|}{0.1270 .1570} & \multicolumn{2}{|c|}{0.1850 .052} \\
\hline $3_{1}$ & 0 & 0 & 0 & 0 & 0 & 0 & 0 & \multicolumn{2}{|c|}{0.0430} & \multicolumn{3}{|c|}{0.0810 .3590} & 0 & 0 & \multicolumn{2}{|c|}{0.0960} & \multicolumn{2}{|c|}{0.1060 .068} \\
\hline$\beta_{2}$ & 0 & 0 & 0 & 0 & 0 & 0 & 0 & \multicolumn{2}{|c|}{0.0610} & 0 & 0 & 0 & 0 & 0 & \multicolumn{2}{|c|}{0.0720} & \multicolumn{2}{|c|}{0.0630 .175} \\
\hline $\mathrm{B}_{3}$ & 0 & 0 & 0 & 0 & 0 & 0 & 0 & 0 & 0 & 0 & \multicolumn{2}{|c|}{0.1460} & 0 & 0 & \multicolumn{2}{|c|}{0.0590} & \multicolumn{2}{|c|}{0.1560 .111} \\
\hline$C_{1}$ & 0 & 0 & 0 & 0 & 0 & 0 & 0 & 0 & 0 & 0 & 0 & 0 & 0 & 0 & \multicolumn{2}{|c|}{0.1400} & 0 & 0.134 \\
\hline $\mathrm{C}_{2}$ & 0 & 0 & 0 & 0 & 0 & 0 & 0 & 0 & 0 & 0 & 0 & 0 & 0 & 0 & 0 & 0 & 0 & 0 \\
\hline$C_{3}$ & 0 & 0 & 0 & 0 & 0 & 0 & 0 & 0 & 0 & 0 & 0 & 0 & 0 & 0 & 0 & 0 & 0 & 0 \\
\hline $\mathrm{C}_{4}$ & 0 & 0 & 0 & 0 & 0 & 0 & 0 & 0 & 0 & 0 & 0 & 0 & 0 & \multicolumn{3}{|c|}{0.1630 .1100} & \multicolumn{2}{|c|}{0.0430 .129} \\
\hline$C_{5}$ & 0 & 0 & 0 & 0 & 0 & 0 & 0 & 0 & 0 & 0 & 0 & 0 & 0 & & 850 & 0 & 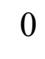 & 0.069 \\
\hline $\mathrm{C}_{6}$ & 0 & 0 & 0 & 0 & 0 & 0 & 0 & 0 & 0 & 0 & 0 & 0 & 0 & \multicolumn{3}{|c|}{0.0730 .1050} & \multicolumn{2}{|c|}{0.0890 .078} \\
\hline$D_{1}$ & 0 & 0 & 0 & 0 & 0 & 0 & 0 & 0 & 0 & 0 & 0 & 0 & 0 & 0 & 0 & 0 & 0 & 0 \\
\hline$D_{2}$ & 0 & 0 & 0 & 0 & 0 & 0 & 0 & 0 & 0 & 0 & 0 & 0 & 0 & 0 & 0 & 0 & 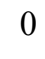 & 0 \\
\hline $\mathrm{D}_{3}$ & 0 & 0 & 0 & 0 & 0 & 0 & 0 & 0 & 0 & 0 & 0 & 0 & 0 & 0 & 0 & 0 & 0 & 0 \\
\hline $\mathrm{D}_{4}$ & 0 & 0 & 0 & 0 & 0 & 0 & 0 & 0 & 0 & 0 & 0 & 0 & 0 & 0 & 0 & 0 & 0 & 0 \\
\hline $\mathrm{D}_{5}$ & 0 & 0 & 0 & 0 & 0 & 0 & 0 & 0 & 0 & 0 & 0 & 0 & 0 & 0 & 0 & 0 & 0 & 0 \\
\hline
\end{tabular}

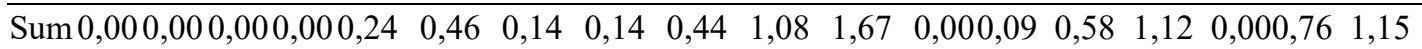


Table 6: Limit super matrix

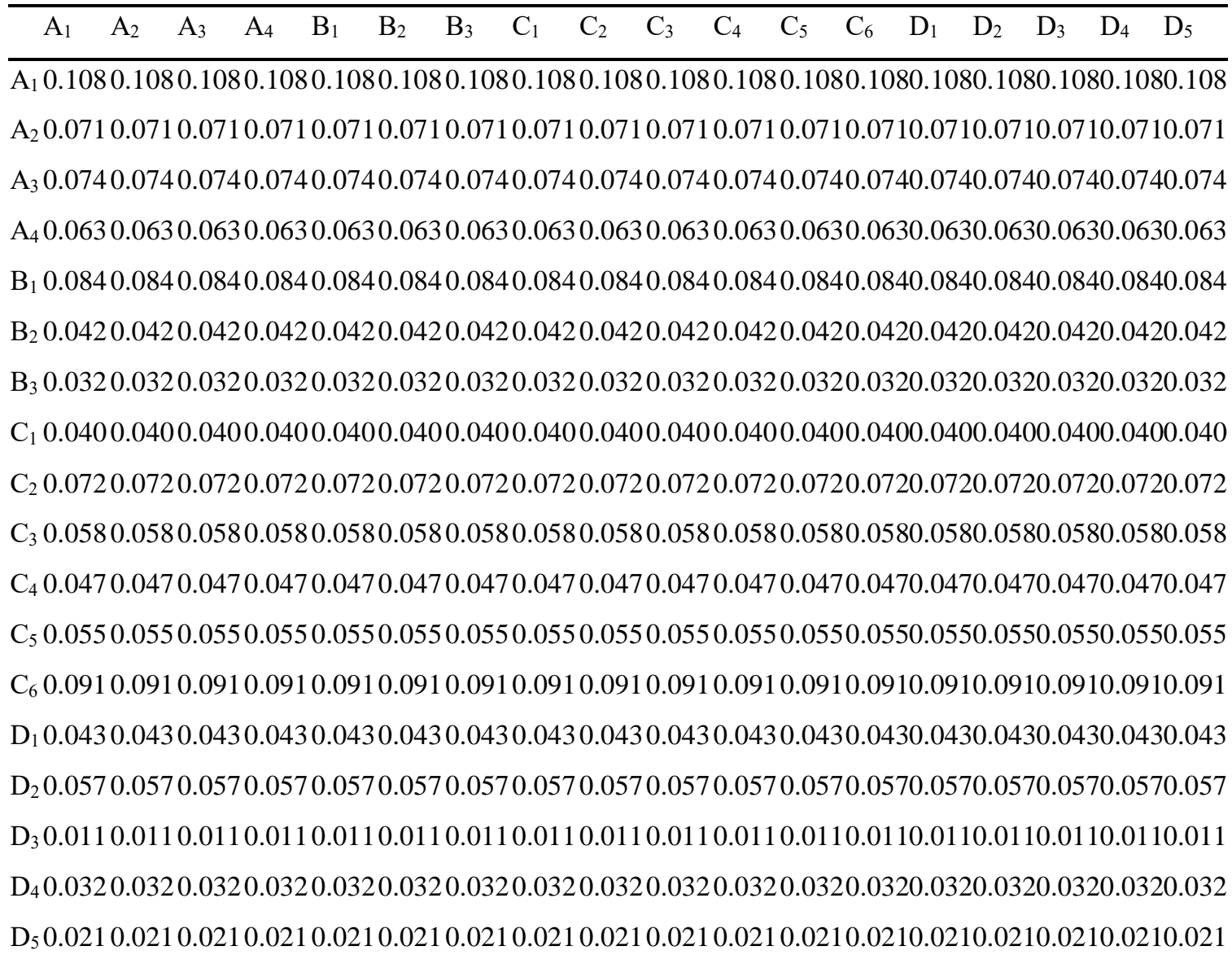

Based on the limited super matrix we calculated the weights of each criterion. Table 6. reflects each criterion weigh in any column which are same along row. Those weights present priority that means $\mathrm{A} 1$ has 10,8\%, $\mathrm{C} 6$ has 9,1\%, B1 has 8,4\%, $\mathrm{A} 3$ has 7,4\% and $\mathrm{A} 2$ has 7,1\% ratio over all. Which initials A1, C6, B1, A3, and A2 gains the highest priority in all.

\section{Conclusion and Discussions}

The application of multi-criteria decision making (MCDM) methods in prioritizing innovation strategy problems related to logistics operations can provide useful insight for decision-makers towards more qualified decisions.

This study demonstrated the application of ANP method which enables interrelationships among the decision levels and attributes in a more general form. This method analyses by integrating interdependent relationships within and among a set of criteria. 
Results shows that for innovation decision most important criterion is firm size (0.108) which is one of the most important factors influencing the decision of long-term or short-term strategies for companies.

Innovation also is a critical strategic decision factor that requires time for the accomplishment of strategic objectives. There are several studies which points out the importance of firm's size related with skilled labor, financial assets etc. The second criterion is management skills (0.091). Top managers encourage entrepreneurial thinking by allowing autonomy to produce creative proposals, obtaining support funding from internal stakeholders, building decision-making consensus among the top management team. And also, they can create an innovative corporate culture by enhancing learning opportunities, and encouraging commitment to learning and risktaking. The next important factor is research and development capacity (0.084). The basic functions of R\&D capabilities of firm is to expand its existing technologies and establish novel technologies or improve R\&D function. Also, analysis presents less important criteria such as infrastructure availability (0.011), competition (0.021), and governmental focus (0.032), respectively.

Table 7: Priority of Innovation criteria

\begin{tabular}{|l|l|l|}
\hline Priority & Criterion & Weights \\
\hline $\mathbf{1}$ & Firm size & 0.108 \\
\hline $\mathbf{2}$ & Management skills & 0.091 \\
\hline $\mathbf{3}$ & Development capacity & 0.084 \\
\hline $\mathbf{\cdots}$ & & \\
\hline $\mathbf{1 6}$ & Governmental focus & 0.032 \\
\hline $\mathbf{1 7}$ & Competition & 0.021 \\
\hline $\mathbf{1 8}$ & Infrastructure availability & 0.011 \\
\hline
\end{tabular}

Depending to the literature, the results underline the importance given to a selected criterion. The decisions taken by the management could be taken more carefully. A future practical implementation can be done by applying different decision making methods such as Fuzzy AHP/ANP, TOPSIS, ELECTRE, and etc. with considering different group of criteria.

\section{References}

Alegre, J., Chiva, R.(2008). Assessing the impact of organizational learning capability on product innovation performance: An empirical test, Technovation , 28, 315-326.

Angeleanu, A. (2015). New Technology Trends and Their Transformative Impact on Logistics and Supply Chain Processes, International Journal of Economic Practices and Theories, Vol. 5, No. 5, 413-419.

Arago'n-Correa, J.A. ,Garcı'a-Morales, V.J., Cordo' n-Pozo, E. (2007). Leadership and organizational learning's role on innovation and performance: Lessons from Spain ,Industrial Marketing Management, 36349 - 359. 
Arora, A., Fosfuri, A., (2003). Licensing the market for technology. J. Econ. Behav. Organ. 52, 277-295.

Baark, E., Lau, Antonio, K.W., William, L. and Sharif, N. (2011). Innovation Sources, Capabilities and Competitiveness: Evidence from Hong Kong Firms. Paper presented at the DIME (Dynamics of Institutions \& Markets in Europe) Final Conference, 6-8 April, 2011, Maastricht, 1-40.

Bayarçelik, E. B., Taşel, F., \& Apak, S. (2014). A research on determining innovation factors for SMEs. Procedia-Social and Behavioral Sciences, 150, 202-211.

Bellingkrodt, S., and Wallenburg, C.M. (2013). The Role of External Relationships for LSP Innovativeness: A Contingency Approach. Journal of Business Logistics 34 (3):20921.

Bontis, N., (2001) Assesing Knowledge Assets: A Review of the Models Used to Mesaure Intellectual Capital, International Journal of Management Reviews, 3(1).

Börjesson, S., Elmquist, M., Hooge, S., (2014). The challenges of innovation capability building: Learning from longitudinal studies of innovation efforts at Renault and Volvo Cars, Journal of Engineering and Technology Management (31),120-140.

Burgelman, R., Maidique, M.A., Wheelwright, S.C., 2004. Strategic Management of Technology and Innovation. McGraw Hill, New York.

Busse, C. (2010). A Procedure for Secondary Data Analysis: Innovation by Logistics Service Providers. Journal of Supply "Chain Management 46(4):44-58.

Busse, C., Wallenburg, C.M. (2011). Innovation management of logistics service providers Foundations, review, and research agenda, International Journal of Physical Distribution \& Logistics Management,(41).2, pp. 187-218.

Calantone, R.J., Cavusgil, S.T., Zhao, Y., (2002). Learning orientation, firm innovation capability, and firm performance. Industrial Marketing Management 31, 515-524.

Chapman, R.L., Soosay, C. and Kandampully, J. (2003). Innovation in logistic services and the new business model: a conceptual framework. International Journal of Physical Distribution \& Logistics Management, Vol. 33 No. 7, pp. 630-50.

Cichosz M., Goldsby T.J., Knemeyer A.M., Taylor D.F. (2017). Innovation in logistics outsourcing relationship - in the search of customer satisfaction. LogForum 13(2), 209219.

Chiesa, V., Coughlan, P., Voss, C.A., (1996). Development of a technical innovation audit. Journal of Product Innovation Management 13, 105-136.

Christensen, J.F., 1995. Asset profiles for technological innovation. Research Policy 24, 727745

Coad, A., Segarra, A., \& Teruel, M. (2016). Innovation and firm growth: Does firm age play a role?, Research Policy (45), 387-400.

Cobo-Benita, J.R., Rodriguez-Segura, E., Ortiz-Marcos, I., Ballesteros-Sanches, L., (2016). Innovation projects performance: Analyzing the impact of organizational characteristics. Journal of Business Research 69, 1357-1360.

Conceicao, P., Heitor, M. V., \& Francisco, V. (2003). Infrastructures, incentives, and institutions: Fostering distributed knowledge bases for the learning society. Technological Forecasting \& Social Change, (70), 583-617.

Covin, J.G., Miles, M.P., (1999). Corporate entrepreneurship and the pursuit of competitive advantage. Entrepreneurship Theory and Practice 23, 47-64.

Dai1, J., Cantor, D.E., Montabon, F.L. (2015). How Environmental Management Competitive Pressure Affects a Focal Firm's Environmental Innovation Activities: A Green Supply Chain Perspective. Journal of Business Logistics, 36(3): 242-259. 
Daugherty, P.J., Chen, H., and Ferrin, B.G. (2011).Organizational Structure and Logistics Service Innovation.”The International Journal of Logistics Management 22(1):29-5.

Daugherty, P.J., Stank, T.P. and Ellinger, A.E. (1998). Leveraging logistics/distribution capabilities: the effect of logistics service on market share. Journal of Business Logistics, Vol. 19 No. 2, pp. 35-5.

Evangelista, R., Perani, G., Rapiti, F., Archibugi, D., (1997). Nature and impact of innovation in manufacturing: some evidence from the Italian innovation survey. Research Policy 26, 521-536.

Fabrizio, K. R., Poczer, S., Zelner, B.A., (2017). Does innovation policy attract international competition? Evidence from energy storage. Research Policy, 46, 1106-1117

Fallah, M.H., Lechler, T.G., (2008). Global Innovation performance: Strategic challenges for multinational corporations. Journal of Engineering and Technology Management, 25, 58-74.

Flint, D.J., Larsson, E., and Gammelgaard, B. (2008). Exploring Processes for Customer Value Insights, Supply Chain Learning and Innovation: An International Study. Journal of Business Logistics 29(1):257-81.

Flint, D.J., Larsson, E., Gammelgaard, B., and Mentzer, J.T. (2005). Logistics Innovation: A Customer Value-Oriented Social Process. Journal of Business Logistics 26(1):113-48.

Flint, D.J., Larsson, E., Gammelgaard, B., Mentzer, J.T., (2005). Logistics Innovation: A Customer Value-Oriented Social Process. Journal of Business Logistics, Vol. 26, No.1, pp.113-147.

Grawe, S.,J., Daugherty, P.J., Roat, A.S., (2011). Knowledge Sythesis and Innovative Logistics Processes: Enhancing Operational Flexibility and Performance. Journal of Business Logistics, Vol.32, No.1, pp. 69-80.

Guan, J., \& Yam, R. C. (2015). Effects of government financial incentives on firms' innovation performance in China: Evidences from Beijing in 1990s. Research Policy, 1(44), $273-$ 282.

Gunsel, A., Siachou E., Acar, A. Z.(2011) Knowledge Management And Learning Capability To Enhance Organizational Innovativeness, Procedia Social and Behavioral Sciences $24,880-888$.

Han, Y., Lin, D., (2014). Effects of intellectual capitalon innovative performance, The role of knowledge-based dynamic capability. Management Decision, 53(1) 1,pp. 40-56.

Hsu, C., Wallace,W.A., (2007). An industrial network flow information integration model for supply chain management and intelligent transportation. Journal Enterprise Information Systems, 1, 327-35.

Hsu, L.C., Wang, C.H. (2012). Clarifying the effect of intellectual capital on performance: the mediating role of dynamic capability. British Journal of Management, Vol. 23 No. 2, pp. 179-205.

Hudson, W.J. (1993), Intellectual Capital: How to Build It, Enhance It, Use It, New York: Wiley. J.

Hult, G.T.M., Hurley, R.F., Knight, G.A., (2004). Innovativeness: its antecedents and impact on business performance. Industrial Marketing Management (33), 429-438.

Hwang, Y.-S., Hwang, M.-H., \& Dong, X. (2015). “The Relationships Among Firm Size, Innovation Type, and Export Performance with Regard to Time Spans”, Emerging Markets Finance \& Trade (51), 947-962.

Jassawalla, A.R., Sarshittal, H.C., (2002). Cultures that support product-innovation processes, Academy of Management Executive 16 (3), 42-54.

Jiebing W, Bin G, Yongjiang S.(2013). Customer knowledge management and IT-enabled business model innovation: A conceptual framework and a case study from China. European Management Journal, 31:359- 372. 
Kim, Y.K., Lee, K., Park, W.G., Choo, K. (2012). Appropriate intellectual property protection and economic growth in countries at different levels of development. Research Policy, Vol. 41, pp. 358-375.

Lin, C.Y, (2008). Determinants of the adoption of technological innovations by logistics service providers in China. International Journal of Technology Management and Sustainable Development, Vol.7, No1.pp. 19-38.

Lin, C.-Y. (2007). Determinants of the Adoption of Technological Innovations by Logistics Service Providers in China. International Journal of Technology Management and Sustainable Development 7(1):19-38.

Luthans, F., Youssef, C.M. (2004). Human, social, and now positive psychological capital management: investing in people for competitive advantage. Organizational Dynamics, Vol. 33 No. 2, pp. 143-160.

Martín-de-Castro, G., Delgado-Verde, M., López-Sáez, P. and Navas-López, J.E. (2011). Towards 'an intellectual capital-based view of the firm': origins and nature. Journal of Business Ethics, Vol. 98 No. 4, pp. 649-662.

Maurer, B. (1999). Innovation and investment under financial constraints and product market competition. International Journal of Industrial Organization, 17, 455-476.

Media, LLC.Morrar, R. (2014). Innovation in Services: A Literature Review. Technology Innovation Management Review (4), 6-14.

Mentzer, J.T., Flint, D.J. and Hult, G.T.M. (2001). Logistics service quality as a segmentcustomized process. Journal of Marketing, Vol. 65 No. 4, pp. 82-104.

Mesjasz-Lech, A., (2015). Effects of IT use in improving customer service logistic processes.Procedia Computer Science, 65, pp.961 - 970.

Nodari, C. H., Bo, G. D., Dorion, E., Olea, P. M., \& Severo, E. A. (2012). Innovation in services: Cases of Brazilian manufacturing industries. African Journal of Business Management, 6 (1), 286-296.

OECD. (2005). Oslo Manual: Guidelines for collecting and interpreting innovation data (3rd ed. b.). OECD Publishing.

Panayides, Ph. M. and So, M. (2005). Logistics service provider-client relationships. Transportation Research E, Vol. 41, No. 3, pp. 179-200.

Patanakul, P. and Pinto J. K. (2014). Examining the roles of government policy on innovation. Journal of High Technology Management Research, Vol. 24, pp. 97-107.

Paunov, C. (2012). The global crises and firms' investments in innovation. Research Policy (41), 24-35.

Pedrosa, A.,Blazevic, V., Jasmand, C., (2015). Logistics innovation development: a micro-level perspective. International Journal of Physical Distribution \& Logistics Management, 45 (4), pp. 313-332.

Pellegrino, G., Savona, M., (2017). No money, no honey? Financial versus knowledge and demand constraints on innovation. Research Policy, 46, 510-521.

Rajaguru R, Matanda MJ. (2013) Effects of inter-organizational compatibility on supply chain capabilities: Exploring the mediating role of interorganizational information systems (IOIS) integration. Industrial Marketing Management; 42:620-63.

Saaty T.L. (1977). A scaling method for priorities in hierarchical structures. Journal of mathematical psychology, 15(3): 234-281.

Saaty T.L. (1980). The Analytic Hierarchy Process. New York, McGraw-Hill.

Saaty T.L (1990) An exposition of the AHP in reply to the paper "Remarks on the analytic hierarchy process". Management Science; 36(3). 
Saaty, T. L. (1996). The analytic network process-decision making with dependence and feedback. Pittsburgh, PA: RWS Publications.

Subramaniam, M., Youndt, M.A. (2005). The influence of intellectual capital on the types ofinnovative capabilities. Academy of Management Journal, Vol. 48 No. 3, pp. 450463.

Sukarmijana, S., Sapong, O.D., (2014). Importance of Intellectual Property for SMEs; Challenges and Moving Forward. UMK Procedia,1,74 - 81.

Sumrit, D., Anuntavoranich, P., (2013). Using DEMATEL Method to Analyze the Causal Relations on Technological Innovation Capability Evaluation Factors in Thai Technology-Based Firms. International Transaction Journal of Engineering, Management, \& Applied Sciences \& Technologies, Volume 4 No.2 pp:81-103.

Sundbo, J., \& Gallouj, F. (1999). Innovation in services in seven European countries. Oslo, Norway: Synthesis Report for EU Comission

Tanskanen, T., Holmström, J., Öhman,M., (2015). Generative Mechanisms of the Adoption of Logistics Innovation:The Case of On-site Shops in Construction Supply Chains. Journal of Business Logistics, 36(2): 139-159.

Un, C.A., (2010). An empirical multi-level analysis for achieving balance between incremental and radical innovations. Journal of Engineering and Technology Management 27 (1), $1-19$.

Viederyte, R. (2016). Organizational and Process Innovations in International Logistics Companies: The Relevance and Expected Benefits. Regional Development Studies, No.3 (20), 134-146.

Wagner, S.M., and Sutter, R. (2012). A Qualitative Investigation of Innovation Between ThirdParty Logistics Providers and Customers. International Journal of Production Economics 140(2):944-58.

Wang, C.H., Lu, I.Y. and Chen, C. B. (2008). Evaluating firm technological innovation capability under uncertainty. Technovation, 28(6), 349-363.

Wang, Y.-M., Wang, Y.-S., Yang, Y.-S., (2010). Understanding the determinants of RFID adoption in the manufacturing industry.Technological Forecasting \& Social Change,77, pp: 803-815.

Wang, X., Dass, M., (2017). Building innovation capability: The role of top management innovativeness and relative-exploration orientation. Journal of Business Research, 76, 127-135.

Wheelwright, S.C., Clark, K.B., (1992). Revolutionizing Product Development-Quantum Leaps in Speed, Efficiency, and Quality. The Free Press, New York.

Whitaker, R., (2007) Validation examples of the Analytic Hierarchy Process and Analytic Network Process. Mathematical and Computer Modelling. Volume 46, Issues 7-8, October 2007, Pages 840-859.

Yam, C.M., Guan, J.C., Pun, K.F., Tang, P.Y., (2004). An audit of technological innovation capabilities in Chinese firms: some empirical findings in Beijing, China. Research Policy 33 (8), 1123-1250.

Yang, J., (2012).Innovation capability and corporate growth: an empirical investigation in China. Journal of Engineering and Technology Management 29 (1), 34-46.

Youndt, M.; Subramaniam, M.; Snell, S. A.(2004). Intellectual capital profiles: An examination of investments and returns. Journal of Management Studies, 41(2), pp. 335-361.

Yu, K., Cadeaux, J., Luo, B. N., (2015). Operational flexibility: Review and meta analysis”, International Journal of Production Economics, 169, 190-202.

Zhou, K.Z., Wu, F. (2010). Technological Capability, Strategic Flexibility, and Product Innovation. Strategic Management Journal, 31, 547-561. 